\title{
Elisabet Helsing: a gifted, wholesome and vibrant personality
}

Elisabet was a steady support and inspiration in my life for almost fifty years. Our relationship spanned so many different periods and contexts in our respective professional and personal doings. In each of them Elisabet was there - near or remote - with inspiration, bubbling with her own ideas and supportive of those of others, bringing in a lot of dedication and not least humour!

Older members of the international nutrition community who in the mid-eighties participated at the annual sessions of the then UN ACC-Sub-Committee on Nutrition (now the UN System Standing Committee on Nutrition), may remember when Elisabet - then nutrition advisor in the WHO Regional Office for Europe in Copenhagen - spontaneously created a surprise-revue as entertainment during a normally humour-poor annual dinner: together with participating Nordic nutrition colleagues she led a friendly-satirical sketch about a UN supraagency to coordinate all coordinating units in the UN that were mandated to coordinate all agencies that did not want to be coordinated! We were given different roles, I for one (then meeting as advisor for Norway) being assigned to sit at the reception desk of this multicoordinating imaginary institution, while Elisabet as a UN agent was constantly and hilariously going on and returning from missions after "having seen the poor". In the main led by Elisabet, this provoked so much fun and laughter that the then chairman of the SCN, the late professor and former head of PAHO, Dr. Abraham Horwitz, demanded a revival the following year. Elisabet and those present of the original group did their best a second time, but realized that such things best remain as memories and so rejected new demands for a third year! But this token example of Elisabet as a humourist underpins the characterization of her enormously rich personality.

My own relation to Elisabet started as a teacher/student link when she, trained as a teacher and already with two extensively breastfed young children, felt she needed a better scientific basis for promoting and defending her passion: the need to enable other mothers to breastfeed their children--while fighting commercial breastmilk substitutes. Having initiated the volunteer mothers' group Ammehjelpen in 1968, inspired by La Leche League in the USA but on a different ideological and clear feminist basis, she took up the study of nutrition at the University of Oslo in 1969. Breastfeeding had never been so low in the country, with medical and other health personnel willingly giving out free samples of mothers' milk substitutes provided by the producing companies. The continued work of Elisabet and colleagues and the presence of Ammehjelpen lifted Norway to the top of the list of industrialized countries with very high breastfeeding rates. Gradually even the medical profession began to support her endeavours which soon spread to other countries as well. Mothers, health professionals and activists drew on her rich authorship of breastfeeding books and manuals. She was involved in the establishment and support of WABA.

Equipped with her new academic credentials, she was in 1973 appointed secretary of the Norwegian branch of the FAO-led Freedom from Hunger Campaign, which was located at the office of the National Nutrition Council at the time. Via her efforts, Norway requested and for many years advocated that breast milk be included on FAO's Food Balance Sheets. This was the start of a long internationally oriented nutrition career, both in Norway and in many parts 
of the world, in service of the Norwegian Government, the League of Red Cross Societies, the World Food Programme and the World Health Organization. People will know her from different epochs; for a revue of some of her commitments, readers are referred to an obituary in the UNSCN Nutrition News No. 1 for 2019:

https://www.unscn.org/uploads/web/news/NUTRITION-NEWS-Issue-2-2019.pdf.

With coinciding interests in the wider aspects of malnutrition as a societal problem and concern, our professional contact developed at her graduation from the University of Oslo and encompassed activities in Norway and abroad, some formal, but as much through simple participation and joint lobbying in various fora regarding nutrition, especially nutrition policy. When we over a few years overlapped in time as employed in two different UN agencies (her twelve years WHO in Copenhagen and my four and a half in IFAD in Rome), we also had rich opportunities to compare notes from the inner life of two token UN bodies - comparing some of their day-to-day realities as seen against their institutional ideals. Despite imbalances noted between these two sets of observations and typically shared with much humour! - we maintained our faithfulness in the United Nations, including with its many drivers for good nutrition

A special conceptual and professional meeting place for us was in the right-to-food movement that had started in Norway around 1980. Elisabet soon became a devoted follower, especially related to babies' right to be breastfed and women's right to breastfeed. She preferred to consider the combination as the legal right of the mother-child dyad - using the term conceived by two of her idols, the legendary professor Derrick Jelliffe and Patrice Jelliffe. Thus, the baby's right to its mother's breastmilk is a 'conditioned' right, which cannot be realized unless the mother has the real opportunity to breastfeed; as such a mother lacking this opportunity should not be criticized for not fulfilling her 'duty'. Too often the two rights are seen as separate while in reality they are heavily intertwined, with states parties to the Convention on the Rights of the Child as well as other human rights instruments having the obligation to realize both.

Against a backdrop of shared professional interests and outlook, our personal friendship was continually thriving. Elisabet was such a great inspiration, always full of encouragement to her academic, professional and personal friends - these relationships often overlapping. She loved her family and brought her children along on many travels when they were young--to their amusement, although they did not always understand why they were in Bangladesh or Niger. At home in Norway she cherished, with her husband Graham Dukes (also formerly WHO), her favourite hobby which was their veteran Rolls Royce car and she loved both driving and fixing it. Their home was open to family and friends, often through inviting to house concerts with promising young musicians.

Elisabet, myself and a few other close women friends from earlier periods in Elisabet's life and work in Norway, re-established regular social contact events two or three times annually during the last decade. The scheme of planned gatherings in our respective homes was maintained after her Parkinson's increasingly kept her out of the regular orbits which she loved so much. We kept memorizing many things of our common past, often spiced with Elisabet's characteristic dry humorous commentaries. During her last year of life, Elisabet's memory of this past did not fail even if her Parkinson's was not cooperative in allowing her to express them as she wanted. After our last full get-together in 2018, she reminded us that we had forgotten to set a date for our next one. Sadly, that date never came to be set again.

We, with many others, will miss Elisabet and the many qualities and virtues that we came to cherish so much. 
Wenche Barth Eide

Emerita, Department of Nutrition, University of Oslo Coordinator, Food Human Rights and Corporations (FoHRC)

https://www.jus.uio.no/smr/english/research/projects/fohrc/ 